\title{
ANALYSIS THE PHYSICAL CONDITION OF WEST KALIMANTAN PRAPON FUTSAL ATHLETES
}

\author{
Rahmat Putra Perdana1, Rubiyatno ${ }^{2}$, Edi Purnomo ${ }^{3}$, Aris Tri Wibowo ${ }^{4}$ \\ Universitas Tanjungpura Pontianak ${ }^{1,2,3}$, SMPN 20 Pontianak $^{4}$ \\ rahmatputraperdana@ fkip.untan.ac.id ${ }^{1}$, rubiyatno@fkip.untan.ac.id ${ }^{2}$, \\ edi.purnomo@ fkip.untan.ac.id ${ }^{3}$, aristriw68@ gmail.com ${ }^{4}$
}

\begin{abstract}
The purpose of this research is this study aims to find out the extent of the physical condition of the preparation of West Kalimantan Prapon futsal athletes in making pre-PON selection so that they can pass the PON event. The sample in this study was athletes Pra PON West Kalimantan consisting of 35 people consisting of 13 men and 22 women. The research method makes the research design using the "One Shot Method" approach, which uses one-time data collection. Data collection techniques use test techniques. The data analysis techniques used in this study used quantitative descriptive statistics by percentage. The results of the data analysis can be concluded: (1) the physical condition factor of abdominal muscle strength and flexibility alone that has excellent average ability. (2). Pushing and pulling power, hand strength, limb strength, togok strength, agility have considerable average ability. (3) The physical components of the explosive power of the limb muscles have less average ability, (4) the physical condition factor of endurance and reaction time has very less ability.
\end{abstract}

Keywords: Component of Physical Condition, Futsal

Accepted: $28^{\text {th }}$ of January 2022

Correspondence author: Rahmat Putra Perdana, Universitas Tanjungpura Pontianak, Indonesia. E-Mail: rahmatputraperdana@fkip.untan.ac.id

DOI http://dx.doi.org/10.31851/hon.v5i1.6459

\section{(c) (i) (2)}

Jurnal Halaman Olahraga Nusantara licensed under a Creative Commons Attribution-ShareAlike 4.0 $\underline{\text { International License }}$

\section{INTRODUCTION}

According to (Lhaksana, 2012), Futsal in its Spanish is "which means indoor soccer. The game of futsal is the same as soccer, what distinguishes from these two games is the number of players, the size of the ball, the size of the field and there are several basic techniques as well that are different. One of the advantages of futsal game is with a small field size so it does not require a very large land like a football field (Okilanda et al., 2018). In the world there are two international futsal bodies, namely AMF (Association Mundial de Futsal) with 
POFI (Indonesian Futsal Sports Association) as its representative in Indonesia and FIFA which oversees football (men and women), futsal, beach football with PSSI as its representative in Indonesia.

An important factor in the achievement of one's futsal achievement is the mastery of basic futsal game skills possessed by the player himself. VO2max forms such as; Basic passing techniques, basic technique of holding the ball (control), basic technique of hull (chipping) basic technique of dribbling (dribbling) and basic technique of shooting the ball (shooting) (Arisman et al., 2021). To be able to master the basic skills of playing good futsal requires regular practice and discipline. Exercise can be done anywhere and anytime (Okilanda et al., 2021).

Optimal futsal performance needs coaching. Coaching must start early, young age is very decisive towards achieving optimal achievement quality in the sport of futsal. Talented young athletes need to process with the coaching process scientifically, then emerge the achievements of athletes as much as possible at certain ages. In addition to coaching, to improve the achievement of playing futsal, many factors need to be considered such as infrastructure facilities, technical ability, training process and motivation of the players in training and matches. So it is expected that players or athletes can produce maximum achievement (Maretno \& Arisman, 2020). Basic skills and good physical condition will play an important role in supporting the performance of the game. The players of the West Kalimantan Pre-PON futsal team in basic skills are certainly no longer in doubt because it is a team formed from the selection or networking conducted by PSSI West Kalimantan conducted from porprov results. However, physical condition will need tests and measurements and evaluations of the extent to which a futsal player can have it (Putra et al., 2020).

Based on the background above, it is necessary to conduct initial status measurement tests of dominant biomotor components for KalBar amateur boxing athletes in preparation for Pre-PON and PON 2020. 


\section{METHOD}

Based on the research that will be carried out, this study is quantitative descriptive research. According to (Prastowo, 2010) descriptive research is research that reveals the facts of what existence, objects, activities and processes are. The method used is a quantitative method through a physical condition test (Nopianto et al., 2020). The data that has been obtained will be assessed by physical condition test scores, then separated by category in established norms. The research method makes the research design using the"One Shot Method"approach that is this study using one-time data collection. The measurement test used is the speed of the athlete's reaction time can be measured by means of a whole body reaction test,the strength of the athlete's hand muscles can be measured by using the hand grip dynamometertest, the strength of the thrust arm muscles by using the Exp dynamometer,limb muscle strength and back by using a back and leg dynamometer test measuring instrument, abdominal muscle strength using sit ups, athlete flexibility can be measured using sit and reach tests, endurance using shuttle run,balance into two parts ranging from with eyes open and eyes closed (Stdaning Stork Test and St daning Stork Test- Blind) and agility test using Quick Feet Test.

\section{DISCUSSION}

\section{Test data and measurement of components of physical condition of strength}

The results of the analysis of the ability of the components of the physical condition of attractive strength(full) of in the category of excellent number of 10 athletes with a percentage $(28.57 \%)$, good category with the number of 8 athletes with presentase (22.86\%), and enough categories amounted to 17 athletes with presentase $(48.57 \%)$. The results of the analysis of the ability of the physical condition componentof the strength to push in the category of excellent numbers amounted to 3 athletes with percentage $(8.57 \%)$, good category with the number of 2 athletes with presentase $(5.71 \%)$, the category is quite 22 athletes with presentase $(62.86 \%)$, and the category of less amounted to 8 athletes with presentase $(22.86 \%)$.

The results of the analysis of the ability of the physical condition component 
of hand strength in the category of excellent numbered 2 athletes with percentage (5.71\%), good category with the number of 5 (14.29\%), the category is quite numbered 16 athletes with presentase $(45.71 \%)$, the category of less numbered 7 athletes with presentase (20\%) and the category is very less numbered 5 athletes with presentase $(14.29 \%)$.

The results of the analysis of the ability of components of the physical condition of the strength of the limbs in the category of both with the number of 8 athletes $(22.86 \%)$, the category is quite 24 athletes with presentase $(68.57 \%)$, the category is less numbered 3 athletes with presentase $(8.57 \%)$. The results of the analysis of the ability of the components of the physical condition of the strength of the togok in the category of both with the number of 9 athletes $(25.71 \%)$, the category is quite 25 athletes with presentase $(71.43 \%)$, the category is less amounting to 1 athlete with presentase $(2.86 \%)$.

\section{Test data and measurement of components of the physical condition of Power Limbs}

The results of the analysis of the ability of components of the physical condition of the power of the limb muscles in the category of excellent numbers amounted to 1 athlete with a percentage $(2.86 \%)$, the good category with the number $1(2.86 \%)$, and the category is quite 3 athletes with presentase $(8.57 \%)$, the category of less numbered 18 athletes with presentase $(51.43 \%)$ and the category is very less numbered 12 athletes with presentase (34.29\%).

\section{Test data and measurement of components of physical condition flexibility}

The results of the analysis of the ability of components of the physical condition of the flexibility of the offender in the category of excellent numbers amounted to 25 athletes with percentage (71.43\%), good category with the number of 6 athletes with presentase $(17.14 \%)$, and the category is quite 4 athletes with presentase $(11.43 \%)$.

Test data and measurement of components of the physical condition of abdominal muscle strength

The results of the analysis of the ability of components of the physical condition of abdominal muscle strength in the category of excellent numbered 34 
athletes with a percentage $(97.14 \%)$. good category with the number of 1 athlete with presentase $(2.86 \%)$.

\section{Test data and measurement of components of physical condition of agility}

The results of the analysis of the ability of the physical condition component of agility in the category of both with the number of 3 athletes $(8.57 \%)$, the category is quite 19 athletes with presentase $(54.26 \%)$, the category is less amounted to 3 athletes with presentase $(8.57 \%)$ and the category of less once amounted to 10 athletes with presentase $(28.57 \%)$.

\section{Test data and measurement of components of physical condition of speed}

The results of the analysis of the ability of components of the physical condition of the strength of the limbs in the category are very good with the number of 1 athlete $(2.86 \%)$, the category is less once amounted to 34 athletes with presentase (97.24\%),

\section{Test data and measurement of components of physical condition of endurance}

The results of the analysis of the ability of components of the physical condition of erobic resistance in the category of both with the number of 1 athlete (2.86\%), the category is quite 2 athletes with presentase $(5.71 \%)$, the category of less amounted to 11 athletes with presentase (31.43\%) and the category of less once amounted to 21 athletes with presentase (60\%).

\section{Test data and component measurements of reaction time physical conditions}

The results of the analysis of the ability of the physical condition component of the reaction time of the foot in the category of both with the number of 6 athletes (17.14\%), the category is quite 12 athletes with presentase $(34.29 \%)$, the category is less amounted to 5 athletes with presentase (14.29\%) and the category of less once amounted to 12 athletes with presentase (34.29\%). The results of the analysis of the ability of the physical condition component of the reaction time of the hands of the offender in the category both with the number of 7 athletes $(20 \%)$, the category is quite 5 athletes with presentase (14.29\%) and the category is quite 18 athletes with presentase (51.43\%) 


\section{Result}

This research aims to find out the extent of the physical condition of the preparation of West Kalimantan Prapon futsal athletes in making selection to qualify for the PON event. From the analysis of data on physical condition measurement test results that obtained other antra results, namely the physical condition factor of attractive and encouraging strength, namely with full up and push up tests that are mostly in the category of sufficient (Arisman \& Noviarini, 2021). The results of the analysis of the ability of the components of the physical condition of attractive strength (full) in the category of excellent number of 10 athletes with a percentage $(28.57 \%)$, good category with the number of 8 athletes with presentase $(22.86 \%)$, and the category is quite 17 athletes with presentase $(48.57 \%)$.

The results of the analysis of the ability of the physical condition component of the strength to push (Push)in the category of excellent numbers amounted to 3 athletes with percentage (8.57\%), good category with the number of 2 athletes with presentase $(5.71 \%)$, the category is quite 22 athletes with presentase $(62.86 \%)$, and the category of less amounted to 8 athletes with presentase $(22.86 \%)$. Furthermore, the results of the analysis of the ability of the physical condition component of hand strength in the category of excellent numbered 2 athletes with a percentage $(5.71 \%)$, good category with the number of $5(14.29 \%)$, the category is quite 16 athletes with presentase $(45.71 \%)$, the category of less numbered 7 athletes with presentase (20\%) and the category is very less numbered 5 athletes with presentase (14.29\%). The results of the analysis of the ability of components of the physical condition of the strength of the limbs in the category of both with the number of 8 athletes $(22.86 \%)$, the category is quite 24 athletes with presentase $(68.57 \%)$, the category is less numbered 3 athletes with presentase $(8.57 \%)$.

The results of the analysis of the ability of the components of the physical condition of the strength of the togok in the category of both with the number of 9 
athletes (25.71\%), the category is quite 25 athletes with presentase $(71.43 \%)$, the category is less amounting to 1 athlete with presentase $(2.86 \%)$.

In the physical condition component of the power of the limb muscles in 35 athletes Prapon futsal Kalbar can be said to be mostly or tend to have less ability amounting to 1 athlete with a percentage (2.86\%), a good category with the number of $1(2.86 \%)$, and a sufficient category of 3 athletes with presentase $(8.57 \%)$, a category of less 18 athletes with presentase (51.43\%) and a very less category of 12 athletes with presentase $(34.29 \%)$.

In the physical condition component of flexibility in 35 athletes Prapon futsal Kalbar can be said to be mostly or tend to have excellent abilities with pencapain in the category of very good numbering 25 athletes with a percentage (71.43\%), good category with the number of 6 athletes with presentase $(17.14 \%)$, and a sufficient category of 4 athletes with presentase (11.43\%).

In the physical condition of abdominal muscle strength in 35 athletes Prapon futsal Kalbar mostly has excellent ability amounting to 34 athletes with a percentage $(97.14 \%)$. good category with the number of 1 athlete with presentase $(2.86 \%)$,

In the physical condition component of agility in 35 athletes Prapon futsal Kalbar can be said to be mostly or tend to have enough ability with the category of good with the number of 3 athletes $(8.57 \%)$, the category is enough to number 19 athletes with presentase $(54.26 \%)$, the category is less numbered 3 athletes with presentase $(8.57 \%)$ and the category of less once amounted to 10 athletes with presentase $(28.57 \%)$.

In the component of the physical condition of endurance in 35 athletes Prapon futsal Kalbar can be said to be mostly or tend to have less ability with a good category explanation with the number of 1 athlete $(2.86 \%)$, the category is enough to number 2 athletes with presentase $(5.71 \%)$, the category is less numbered 11 athletes with presentase (31.43\%) and the category of less once amounted to 21 athletes with presentase (60\%). 
In the physical condition component of hand and foot reaction time in 35 athletes Prapon futsal Kalbar can be said to be mostly or tend to have less ability to be in the category of either with the number of 6 athletes $(17.14 \%)$, the category is quite 12 athletes with presentase (34.29\%), the category of less number 5 athletes with presentase $(14.29 \%)$ and the category of less once amounted to 12 athletes with presentase (34.29\%). The results of the analysis of the ability of the physical condition component of the reaction time of the hands of the offender in the category both with the number of 7 athletes (20\%), the category is quite 5 athletes with presentase $(14.29 \%)$ and the category is quite 18 athletes with presentase $(51.43 \%)$.

\section{CONCLUSION}

Based on the results of the analysis of research data on 35 West Kalimantan Prapon futsal athletes can be said that the physical condition factor of abdominal muscle strength and flexibility alone has excellent average ability, while the strength of pushing and pulling, hand strength, limb strength, strength, agility has sufficient average ability, the physical component of leg muscle explosiveness has less average ability, In addition, for the physical condition factor of endurance, reaction time has a very lack of ability.

\section{REFERENCES}

Adiatmika, I P G, and IGPNA Santika. 2013. "Bahan Ajar Tes Dan Pengukuran Olahraga."

Agus Susworo D.M \& Saryono. (2012). Tes Futsal FIK Jogja. Yogyakarta: FIK UNY.

Arisman, A., \& Noviarini, T. (2021). Tabata Workout dalam Meningkatkan Kebugaran Atlet Panahan. Halaman Olahraga Nusantara (Jurnal Ilmu Keolahragaan), 4(1), 12-22.

Arisman, A., Okilanda, A., Dwiansyah Putra, D., \& El Cintami Lanos, M. (2021). Resistensi Yoga dalam Meningkatkan Konsentrasi Ketepatan Memanah. Jurnal Patriot, 3, 71-81. https://doi.org/10.24036/patriot.v

Ibnu Fatkhu Royana. 2017 Analisis Kondisi Fisik Pemain Tim Futsal Upgris. Jurnal Pendidikan Universitas PGRI Semarang

Jonas, Solissa. 2016. Teori Dan Metodelogi Latihan Fisik. 1st Ed. Jakarta: 
Rajagrafindo Persada.

Komarudin. (2011). Dasar Gerak Sepakbola. Diktat Pembelajaran. Yogyakarta: FIK UNY.

Lhaksana, Justinus. (2012). Teknik dan Strategi Futsal Modern. Jakarta: Be Champion

Maretno, M., \& Arisman, A. (2020). Ladder Drill dalam Meningkatkan Kelincahan Atlet Bola Voli. Jurnal Muara Olahraga, 3(1), 1-20.

Nopianto, W., El Cintami Lanos, M., \& Arisman, A. (2020). The Effect of Mixed Inpact Aerobic Gymnam on The Improvement of Physical Fitness for High School. JIPES, 6(2), 55-61.

Okilanda, A., Arisman, A., Lestari, H., Lanos, M. E. C., Fajar, M., Putri, S. A. R., \& Sugarwanto, S. (2018). Sosialisasi Petanque Sebagai Olahraga Masa Kini. Jurnal Bagimu Negeri, 2(1), 69-76. https://doi.org/10.26638/jbn.638.8651

Okilanda, A., Dlis, F., Humaid, H., Putra, D. D., Arisman, A., \& Muslimin, M. (2021). Defense Warm-Up Exercise Material for 13-Age Athlete Using Video Technology in Covid-19 Era. International Journal of Human Movement and Sports Sciences, 9(4), 629-634. https://doi.org/10.13189/saj.2021.090404

Putra, D. D., Okilanda, A., Arisman, A., Lanos, M. E. C., Putri, S. A. R., Fajar, M., Lestari, H., \& Wanto, S. (2020). Kupas Tuntas Penelitian Pengembangan Model Borg \& Gall. Wahana Dedikasi : Jurnal PkM Ilmu Kependidikan, 3(1), 46. https://doi.org/10.31851/dedikasi.v3i1.5340

Saifudin, Azwar. 2016. Metode Penelitian. yogyakarta: pustaka pelajar.

Sireger, Yunita Lasma, and Hasan Sidik. 2016. "Pengaruh Metode Latihan Triangle

Run Terhadap Daya Tahan (Vo2max) Pada Anggota Ekstrakulikuler Sepakbola SMA Negeri 1 Cabangbungin." Motion: Journal Research of Physical Education 7(1) 